\title{
Study on Decision Making Process with reference to Risk Taking Behaviour of Rural Woman Vegetables Growers in Jobat Block of Alirajpur District, Madhya Pradesh, India
}

\author{
Sarala Chouhan ${ }^{1}$, Dr. Sandhya Choudhary ${ }^{2}$, Dr. V. K. Swarnakar ${ }^{3}$ \\ ${ }^{1}$ M.Sc. Extension Education Final Year Student 2015 \\ ${ }^{2}$ Associate Professor Extension Education, College of Agriculture, Indore \\ ${ }^{3}$ Professor \& Head Extension Education, College of Agriculture, Indore
}

\begin{abstract}
Vegetable are grown in almost all the states in the country under varied agro-climatic and soil conditions. India is the second largest producers of vegetables in the world accounting for about12.00 per cent of the world production. risk taking refers to the tendency to engage in behaviour that have the potential to be harmful or dangerous, yet at the same time provide the opportunity for some kind of outcome that can be perceived as positive. The behaviour of rural farm women is guided by individual objective estimate of the degree of risk involved in the vegetable cultivation. The main reason behind them is that women cannot take extra risk about the vegetable cultivation. Keeping in view this point it has been decided to undertake 120 farm women from tribal district for the study. The most of the rural women performed overall high and medium decision making process regarding vegetable production activities followed by low decision. Women were perceived possessing overall medium risk taking behavior regarding vegetable production activities followed by high and low risk.
\end{abstract}

Keywords: Decision Making, Risk Taking Behaviour, Vegetables Growers, Rural Woman

\section{Introduction}

Vegetable is a very important produce which is commonly used in daily human diet. The vegetable production of our country before independence was merely 15 million tonnes and upto year 2001-02 it was about 88.6 million tonnes, accounting to $11.4 \%$ share of world vegetable production. India is the second largest producer of vegetables after China and is a leader in the production of peas and okra. Besides, India occupies the second position in the production of brinjal, cabbage, cauliflower, onion, potato and is third in tomato production in the world. Vegetables that are produced in abundance are potato, onion, tomato, brinjal, okra, cucurbits, etc. Vegetables occupy 8.49 million hectares with a total production of 149.61 million tonnes having a productivity of 17.42 tonnes per hectares. The area under vegetables in India increased from 6 million ha in 2001-02 to 8.49 million hectares during 2011-12.

Not only in India but global vegetable trade is growing steadily and has registered an annual growth of about 5 per cent during last 2 decades. India can become one of the largest exporters of vegetables in the world due to prevalence of diverse agro-climatic conditions and rich variability available in genetic resource of vegetable crops with an important remunerative product.

Women contribute more than half of the duties and responsibilities of the family but are hardly empowered to participate in decision making. Earlier they were not given any rights; they were supposed to do domestic work and to look after children. Gradually with the passage of time, the concept of "working women" came into existence. Women began to come out of the domestic sphere and have begun to take up professional roles in respect of role performance behaviour and decision making process outside their homes particularly in agriculture enterprise where role is found more essential. This has helped them to realize their potential, to broaden their outlook and to create a new meaning in their lives. The traditional role of a housewife has gradually evolved into the dual and more fulfilling role of a working woman and housewife. Keeping in mind the importance of women in role performance and decision making process, the present study entitled "Study on decision making process with reference to risk taking behavior of rural women vegetable growers in Jobat block of Alirajpur district M.P" had been undertaken with the specific objective.

\section{Objectives}

1) To know the role of rural women in decision making process related to vegetable cultivation practices.

2) To ascertain the risk taking behaviour of rural women vegetable cultivators.

\section{Review of Literature}

\section{Risk Taking Behavior}

Jaiswal (2009) reported that maximum numbers of farm women46.7 per cent of respondents had low risk taking behaviour.

Dhanotiya (2012) reported that maximum numbers of farm women were found to possess medium risk taking behaviour followed by low and high respectively. 


\section{International Journal of Science and Research (IJSR) \\ ISSN (Online): 2319-7064 \\ Index Copernicus Value (2013): 6.14 | Impact Factor (2014): 5.611}

Jain and Prashad (2012) reported that in India, agricultural risks are exacerbated by a variety of factors, ranging from climate variability and change, frequent natural disasters, uncertainties in yields and prices, weak rural infrastructure, imperfect markets and lack of financial services including limited span and design of risk mitigation instruments such as credit and insurance. These factors not only endanger the farmer's livelihood and incomes but also undermine the viability of the agriculture sector and its potential to become a part of the solution to the problem of endemic poverty of the farmers and the agricultural labor.

Shashi Kiran and Umesh (2012) reported that the enterprise of agriculture is subject to lot many uncertainties. Still, more people in India earn their livelihood from this sector, than from all other economic sectors put together. Agriculture is associated with several risks which include adverse changes in both input and output prices, Agricultural risk can be categorized as production risk, price or market, financial or credit, and institutional risks etc. The farmers are not assured of good quality and disease free crop which is essential for obtaining reasonable yield sufficient to recover expenses.

\section{Role of rural women in decision making process}

Devalatha (2005) reported that regarding decision making skills 53.33 per cent of women were taking decisions by considering the personal, social and situational dimensions of the decision area.

Praveena et.al. (2005) revealed that though rural farmwomen followed all the considered methods for decision making depending on the nature of farm activity, majority of rural women belied on joint decisions by consulting their spouse. However, the respondents were mostly self reliant in deciding few aspects like gap filling, storage and dairying. Form the findings it could be concluded that the farm women did not prefer to take self decisions especially in all the market related activities such as selection and procurement of seed materials, purchase/ selling of other agricultural inputs, disposal of the farm produce etc.

Singh et.al. (2005) reported that the higher numbers of females 72 per cent were observed in the medium category of decision making, while 13 and 12 per cent were found in the categories of low and high decision making respectively when the data described on pooled basis. 3 per cent females were found such who did not take part in decision making.

Waman and Rahane (2005) studied that women engaged in Bidi making occupation either take self decisions or have equal participation with other family members with respect to decision regarding family affairs.

Kavita (2006) concluded that the operational decisions of farmwomen from 20-26 per cent had taken their own decisions, while 54.82 per cent of the rural women had consulted their spouse, to take decision regarding all the activities. The farm women from 14 per cent had consulted all their family members and friends to take decisions and 4.28 per cent of rural women had never participated in decision-making of farming system.

\section{Material \& Methods}

The Alirajpur district comprises of 6 blocks namely Alirajpur, Bhabara, Udaygad, Sondwa, Katthiwada and Jobat. Out of these blocks Jobat block was selected purposively because this block has maximum area of vegetable cultivation, grown by rural women. A list of vegetable growing villages was prepared with the help of horticulture and extension officials of Block office Jobat. Out of these villages, 10 villages were selected with random sampling method. A village wise list of rural women vegetable growers of each selected villages was prepared with the help of RHEOs/RAEOs. Out of which 120 women vegetable growers were selected randomly. The data was collected personally by the researcher through a structured and pre-tested interview schedule. The researcher personally approached the respondents and explained to them about the purpose of this study.

\section{Result \& Discussion}

Role of rural women in decision making process related to vegetable cultivation practices:

It appeared that any decision taken was strongly influences by the ability, attitude and opinion of their partners, therefore, a proper understanding of the complicity of the decision making process in rural families and ascertaining the role of rural women in the process of decision making which will helps in toning up agricultural modernization in the country as well as transformation of rural family life. In detail regarding distribution of rural women in respect to their decision making process in vegetable cultivation practices was presented in Table.

Table: Distribution of rural women according to their decision making process in vegetable cultivation practices.

$$
\mathrm{N}=120
$$

\begin{tabular}{|c|c|c|c|c|c|c|}
\hline Practices & $\begin{array}{c}\text { Low } \\
\text { decision }\end{array}$ & $\begin{array}{c}\text { Medium } \\
\text { decision }\end{array}$ & $\begin{array}{c}\text { High } \\
\text { decision }\end{array}$ & $\begin{array}{c}\text { Mean } \\
\text { score }\end{array}$ & Rank & $\begin{array}{c}\text { Overall } \\
\text { level }\end{array}$ \\
\hline $\begin{array}{c}\text { Preparation of } \\
\text { land }\end{array}$ & 28 & 49 & 43 & 2.13 & $\mathrm{VI}^{\text {th }}$ & medium \\
\hline $\begin{array}{c}\text { Selection of } \\
\text { crop }\end{array}$ & 27 & 41 & 52 & 2.21 & $\mathrm{I}^{\text {st }}$ & high \\
\hline $\begin{array}{c}\text { Selection of } \\
\text { seed variety }\end{array}$ & 31 & 41 & 48 & 2.14 & $\mathrm{~V}^{\text {th }}$ & medium \\
\hline Quantity of seed & 35 & 43 & 42 & 2.06 & $\mathrm{X}^{\text {th }}$ & low \\
\hline Seed treatment & 27 & 43 & 50 & 2.19 & $\mathrm{II}^{\text {nd }}$ & high \\
\hline Sowing time & 32 & 47 & 41 & 2.08 & $\mathrm{IX}^{\text {th }}$ & low \\
\hline $\begin{array}{c}\text { Irrigation } \\
\text { management }\end{array}$ & 31 & 49 & 40 & 2.08 & $\mathrm{IX}^{\text {th }}$ & low \\
\hline Weed control & 29 & 42 & 49 & 2.17 & $\mathrm{III}^{\text {rd }}$ & high \\
\hline $\begin{array}{c}\text { Fertilizer } \\
\text { application }\end{array}$ & 31 & 45 & 44 & 2.11 & $\mathrm{VII}^{\text {th }}$ & medium \\
\hline $\begin{array}{c}\text { Manure } \\
\text { application }\end{array}$ & 38 & 41 & 41 & 2.03 & $\mathrm{XI}^{\text {th }}$ & low \\
\hline Plant protection & 33 & 44 & 43 & 2.08 & $\mathrm{IX}^{\text {th }}$ & low \\
\hline $\begin{array}{c}\text { Picking of } \\
\text { vegetable }\end{array}$ & 31 & 46 & 43 & 2.10 & $\mathrm{VIII}^{\text {th }}$ & medium \\
\hline Storage & 25 & 52 & 43 & 2.15 & $\mathrm{IV}^{\text {th }}$ & medium \\
\hline Marketing & 28 & 47 & 45 & 2.14 & $\mathrm{~V}^{\text {th }}$ & medium \\
\hline Overall average & 30 & 45 & 45 & 2.12 & & medium \\
\hline
\end{tabular}




\section{International Journal of Science and Research (IJSR) \\ ISSN (Online): 2319-7064 \\ Index Copernicus Value (2013): 6.14 | Impact Factor (2014): 5.611}

The perusal of data presented in Table revealed that the rural women appeared in decision making process in each and every activities of vegetable cultivation but their extent in decision making process in different activities in vegetable cultivation process found to variation. The data revealed that at high level activities in which rural women took their decision were selection of crop (mean score 2.21) followed by seed treatment (mean score 2.19) and weed control (mean score 2.17 each) respectively.

The data revealed that at medium level activities in which rural women took their decision were storage (mean score 2.15) followed by selection of seed variety and marketing (mean score 2.14 each), preparation of land (mean score 2.13), fertilizer application (mean score 2.11) and picking of vegetable (mean score 2.10) respectively.

The data revealed that at low level activities in which rural women took their decision were plant protection, sowing time and irrigation management (mean score 2.08 each) followed by quantity of seed (mean score 2.06 each) and manure application (mean score 2.03 ) respectively.

Thus, it may be concluded that the rural women appeared in decision making process was found to be as medium level among all the activities in vegetable cultivation with overall mean score 2.12. With respect to vegetable cultivation activities in which the rural women took highest decision and the foremost were selection of crop followed by seed treatment and weed control.

\section{Overall decision making process of rural women in vegetable cultivation:-}

In rural areas due to certain socio-personal factors the rural women were not able to make their decision in respect of vegetable production process. But the data of study revealed that they are appeared in decision making process with respect to all activities in some extent. In detail the overall extent of decision making process of rural women in different vegetable production activities was presented in Table below.

Table: Distribution of rural women according to their decision making process in vegetable production activities.

$$
\mathrm{N}=120
$$

\begin{tabular}{|c|c|c|c|}
\hline S.No. & Categories & Frequency & Percentage \\
\hline 1 & Low & 30 & $\mathbf{2 5 . 0 0}$ \\
\hline 2 & Medium & 45 & $\mathbf{3 7 . 5 0}$ \\
\hline 3 & High & 45 & $\mathbf{3 7 . 5 0}$ \\
\hline & Total & 120 & $\mathbf{1 0 0 . 0 0}$ \\
\hline
\end{tabular}

The data presented in Table showed that majority of the rural women 37.50 per cent performed overall high and medium decision in vegetable production process followed by low decision 25.00 per cent respectively.

Thus, it can be concluded that in study area, most of the rural women performed overall high and medium decision making process regarding vegetable production activities followed by low decision.

\section{Risk taking behaviour of rural women vegetable} cultivators.

The actual behavior of people when facing a risk situation is known as risk taking behaviour. A better understanding of how rural women risk is perceived in vegetable cultivation is a crucial step in becoming more effective women risk taking behaviour to community of vegetables growers. Accurate risk perception, however, does not ensure effective prevention, mitigation or defensive action. Promoting effective risk-related behavior involves understanding not only how perception occurs, but how rural women vegetables growers make decisions, particularly decisions made under stress. In detail regarding distribution of rural women in respect to their risk taking behaviour in vegetable cultivation practices was presented in the present Table

Table: Distribution of rural women according to their risk taking behaviour in vegetable cultivation practices. $\mathrm{N}=120$

\begin{tabular}{|c|c|c|c|c|c|c|}
\hline Practices & $\begin{array}{c}\text { Low } \\
\text { risk }\end{array}$ & $\begin{array}{c}\text { Medium } \\
\text { risk }\end{array}$ & $\begin{array}{c}\text { High } \\
\text { risk }\end{array}$ & $\begin{array}{c}\text { Mean } \\
\text { score }\end{array}$ & Rank & $\begin{array}{c}\text { Overall } \\
\text { level }\end{array}$ \\
\hline $\begin{array}{c}\text { There is economic risk } \\
\text { in vegetable } \\
\text { cultivation. }\end{array}$ & 31 & 40 & 49 & 2.15 & $\mathrm{II}^{\text {nd }}$ & High \\
\hline $\begin{array}{c}\text { There is higher return } \\
\text { over cost incurred in } \\
\text { cultivation of } \\
\text { vegetable. }\end{array}$ & 30 & 47 & 43 & 2.11 & III $^{\text {rd }}$ & High \\
\hline $\begin{array}{c}\text { There is storage risk in } \\
\text { vegetable cultivation. }\end{array}$ & 31 & 39 & 50 & 2.16 & $\mathrm{I}^{\text {st }}$ & High \\
\hline $\begin{array}{c}\text { The social functioning } \\
\text { and standard of rural } \\
\text { women decrease when } \\
\text { they are cultivating } \\
\text { vegetable. }\end{array}$ & 54 & 37 & 29 & 1.79 & $\mathrm{VII}^{\text {th }}$ & Low \\
\hline $\begin{array}{c}\text { In vegetable } \\
\text { cultivation the } \\
\text { cooperation of family } \\
\text { members are not } \\
\text { satisfactory. }\end{array}$ & 33 & 43 & 44 & 2.09 & $\mathrm{IV}^{\text {th }}$ & High \\
\hline $\begin{array}{c}\text { There is no fair market } \\
\text { due to political } \\
\text { pressure. }\end{array}$ & 32 & 48 & 40 & 2.07 & $\mathrm{~V}^{\text {th }}$ & High \\
\hline $\begin{array}{c}\text { There is additional } \\
\text { working pressure in } \\
\text { vegetable cultivation. }\end{array}$ & 34 & 44 & 42 & 2.07 & $\mathrm{~V}^{\text {th }}$ & High \\
\hline $\begin{array}{c}\text { There is good effect on } \\
\text { health in vegetable } \\
\text { cultivation. }\end{array}$ & 35 & 45 & 40 & 2.04 & $\mathrm{VI}^{\text {th }}$ & High \\
\hline $\begin{array}{c}\text { The management } \\
\text { process is necessary in } \\
\text { vegetable cultivation }\end{array}$ & 58 & 32 & 30 & 1.77 & $\mathrm{VIII}^{\text {th }}$ & Low \\
\hline $\begin{array}{c}\text { Overall average } \\
\text { nomeram }\end{array}$ & 38 & 42 & 41 & 2.03 & & Medium \\
\hline
\end{tabular}

The perusal of data presented in Table 4.16 revealed that the rural women taking risk in each and every activities of vegetable cultivation but their extent in risk taking behaviour in different activities in vegetable cultivation process found to variation. The data revealed that at high level risk taking behaviour of rural women activities were storage risk in vegetable cultivation (mean score 2. 16) followed by economic risk (mean score 2.15), higher return than cost of cultivation (mean score 2.11), no cooperation of family member (mean score 2.09), now fair market and additional work pressure (mean score 2.07 each) and good effect on health (mean score 2.04) respectively. 


\section{International Journal of Science and Research (IJSR) \\ ISSN (Online): 2319-7064 \\ Index Copernicus Value (2013): 6.14 | Impact Factor (2014): 5.611}

On the other hand, low level risk taking behaviour of rural women activities were social functioning and standard of rural women decreased (mean score 1.79) followed by management process is necessary (mean score 1.77) respectively.

Thus, it may be concluded that the rural women's risk taking behaviour was found to be of medium level among all the activities in vegetable cultivation with overall mean score 2.03. With respect to vegetable cultivation activities in which the rural women perceived highest risk and the foremost were storage risk in vegetable cultivation followed by economic risk, higher return than cost of cultivation, no cooperation of family member, now fair market and additional work pressure and good effect on health.

Overall risk taking behaviour of rural women in vegetable cultivation

There are several risks performing in vegetable cultivation. The study revealed that rural women perceived risk in each and every process of vegetable cultivation but the extent of risk taking behaviour varied from process to process. In detail the overall extent of risk taking behaviour of rural women in different vegetable production activities was presented in following Table.

Table: Distribution of rural women according to their risk taking behaviour in vegetable production activities. $\mathrm{N}=120$

\begin{tabular}{|c|c|c|c|}
\hline S.No. & Categories & Frequency & Percentage \\
\hline 1 & Low & 38 & $\mathbf{3 1 . 6 7}$ \\
\hline 2 & Medium & 42 & $\mathbf{3 5 . 0 0}$ \\
\hline 3 & High & 40 & $\mathbf{3 4 . 1 7}$ \\
\hline & Total & 120 & $\mathbf{1 0 0 . 0 0}$ \\
\hline
\end{tabular}

The data presented in Table showed that majority of the rural women 35.00 per cent perceived overall medium risk taking behaviour in vegetable production process followed by high 34.17 per cent and low risk taking behaviour 31.67 per cent respectively.

Thus, it can be concluded that in study area, most of the rural women perceived overall medium risk taking behaviour regarding vegetable production activities followed by high and low risk.

Role of rural women in decision making process related to vegetable cultivation practices

Higher percentage of the rural women vegetable growers performed overall high and medium decision making process regarding vegetable production activities. This attributes might be family norms, social obligation, low confidence, average literacy position beside ever changing agro climatic conditions, lack of motivation made this situation.

Risk taking behaviour of rural women vegetable cultivators

Higher percentage of the rural women vegetable growers were perceived to have overall medium risk taking behaviour regarding vegetable production activities. The uncertainty of agro climatic situation blended with price fluctuation and unstable market might have favoured the existing situation.

\section{References}

[1] Devalatha,C.M. (2005). Profile study of women self help groups in Gadag district of Northern Karnataka. M.Sc.(Agri.) Thesis submitted to the University of Agricultural sciences, Dharwad.

[2] Dhanotiya,B. (2012). Study of women entrepreneurial behavior in Self Help Group through KVK Kasturba Gram Indore district of M.P. M.Sc.(Agri.) Thesis submitted to R.V.S.K.V.V. Gwalior.

[3] Jain,R.C.A and M.Prashad (2012). Risk Management in Agriculture. Report for the eleventh five year plan (20072012).

[4] Jaiswal Aparna (2009). A study on entrepreneurial behaviour of rural woman entrepreneurs in Indore block of Indore district (M.P.). M.P. M.Sc.(Agri.) Thesis submitted to J.N.K.V.V. Jabalpur.

[5] Kavita (2006). A study on the women participation of farm operations and decision making in agriculture. Extension Education and Management. 15(4):26-30.

[6] Praveena et.al. (2005). Decision making pattern of rural women in farm related activities. Agriculture Extension Review November 3-7.

[7] Shashi, Kiran A.S and K.B.Umesh (2012). Crop Insurance - Strategy to minimize risk in Agriculture. Triennial Conference, Foz do Iguaçu, Brazil, 18-24 August, 2012.

[8] Singh,S.P; L.P.Gite; Nirmal Kumar and Nidhi Agrawal (2005). Involvement of farmwomen of Vindhya Plateau. Agricultural Extension Review March - April pp:20-26. 